\title{
TANGGUNG JAWAB PIHAK KONSINYOR YANG MELAKUKAN WANPRESTASI DALAM PERJANJIAN KONSINYASI PADA PT. DOWN TO EARTH
}

\author{
A.A.A. Ngr. Sri Rahayu Gorda(1) \\ srigorda@undiknas.ac.id ${ }^{(1)}$
}

\section{Fakultas Hukum dan IImu Sosial Undiknas Denpasar}

\begin{abstract}
PT. Down To Earth is one of the company that applied the consignment system in Seminyak. The consignment system is based on trust by consignor through an agreement that created by PT. Down To Earth. But in reality, sometimes there is a problem occurs that result in a breach of contract. Based on the record, there are three kinds of breach of contract noted, which usually happened in (delivery of product, invoice received and loss product). This, atter needs to be resolved so we can maintain a good relationship that balancing between right and obligations according to the agreement that has been agreement agreed by booth parties. This objective of this paper is to give accountability for consignor and comprehension in resolving breaches of contract's issues. This paper is written with empirical method and data analysis technique ehich is analytical descriptive. Based on research on the consignment agreement, there is still a lot of breach of contract occurred in PT. Down To Earth either is caused by the location of the warehouse that hard to reach by tho consignor or the consignor has a close relationship to the owner of PT. Down To Earth. Most of the breach of contract's issues solved by nonlitigation method which was negotiation \& mediation.
\end{abstract}

Keywords: Consigment Agreement, Breach of Contract, and Responsibility

\begin{abstract}
ABSTRAK
PT. Down To Earth adalah salah satu perusahaan yang menerapkan sistem konsinyasi di Seminyak. Sistem konsinyasi didasarkan pada kepercayaan oleh pengirim melalui perjanjian yang dibuat oleh PT. Merendah. Namun dalam kenyataannya, terkadang ada masalah yang terjadi yang mengakibatkan pelanggaran kontrak. Berdasarkan catatan, ada tiga jenis pelanggaran kontrak dicatat, yang biasanya terjadi di (pengiriman produk, faktur diterima dan produk kerugian). Ini, atter perlu diselesaikan sehingga kita bisa menjaga hubungan baik yang menyeimbangkan antara hak dan kewajiban sesuai kesepakatan yang sudah disepakati bersama oleh pihak-pihak stan. Tujuan dari makalah ini adalah untuk memberikan akuntabilitas bagi pengirim dan pemahaman dalam menyelesaikan pelanggaran masalah kontrak. Tulisan ini ditulis dengan metode empiris dan teknik analisis data yang bersifat analitis deskriptif. Berdasarkan penelitian tentang perjanjian konsinyasi, masih banyak terjadi pelanggaran kontrak di PT. Down To Earth baik disebabkan oleh lokasi gudang yang sulit dijangkau oleh pengirim atau pengirim memiliki hubungan dekat dengan pemilik PT. Merendah. Sebagian besar pelanggaran masalah kontrak diselesaikan dengan metode non-litigasi yang merupakan negosiasi \& mediasi.
\end{abstract}


Kata Kunci: Perjanjian Konsinyasi, Pelanggaran Kontrak, dan Tanggung Jawab

\section{PENDAHULUAN}

Setiap perusahaan memiliki tujuan untuk mencapai keuntungan yang maksimal. ${ }^{1}$ Berbagai upaya dilakukan untuk mencapai tujuan tersebut. Cara mencapai tujuannya setiap perusahaan mengarahkan kegiatan usahanya untuk menghasilkan produk yang dapat memberikan kepuasan terhadap konsumen, sehingga perusahaan mendapatkan keuntungan sesuai yang diharapkan. Akibat dari gejala tersebut menyebabkan munculnya banyak perjanjian kerjasama diantara para pengusaha yang bertujuan untuk memperoleh keuntungan dan perputaran roda perekonomian para pengusaha yang semakin membaik dan juga untuk memenuhi kebutuhan masyarakat.

Perjanjian kerjasama yang digunakan dalam praktek sehari-hari mempunyai sebutan nama tertentu, tetapi tidak diatur di dalam peraturan perundang-undangan, karena saat ini di Indonesia belum diberikan pengaturan secara khusus. Pasal 1319 Kitab Undang-Undang Hukum Perdata (KUHPerdata) menyebutkan dua kelompok perjanjian, yaitu perjanjian yang oleh undang-undang diberikan suatu nama khusus disebut dengan perjanjian bernama (benoemde atau nominaatcontracten) dan perjanjian yang dalam undang-undang tidak dikenal dengan suatu nama tertentu yang disebut perjanjian tak bernama (onbenoemde atau innominaat contracten). ${ }^{2}$

Ada beberapa contoh perjanjian sewa beli, salah satu perjanjian tak bernama atau innominaat yang terkenal di dunia kerjasama dan bisnis adalah perjanjian konsinyasi atau yang biasa disebut perjanjian bagi hasil atau titip jual dimana timbulnya perjanjian ini karena adanya asas kebebasan berkontrak. ${ }^{3}$ Perjanjian konsinyasi ini merupakan jenis

${ }^{1}$ Frans M. Royan, 2004, Creating Effective Sales Force, Ed.2, CV. Andi Offset, Jakarta, h. 1.

2 Sri Gambir Melati Hatta, 2000, Beli Sewa Sebagai Perjanjian Tak Bernama: Pandangan Masyarakat dan Sikap Mahkamah Agung Indonesia, Alumni, Bandung, h.124-125.

${ }^{3}$ Aliminsyah dan Padji, 2003, Kamus Istilah Keuangan dan Perbankan, Yrama Widya, Bandung, h. 77. 
kontrak innominaat, hukum kontrak innominaat adalah keseluruhan kaidah hukum yang mengkaji berbagai kontrak yang timbul, tumbuh, dan hidup dalam masyarakat dan kontrak ini belum dikenal pada saat KUHPerdata diundangkan. ${ }^{4}$

Perjanjian kerjasama konsinyasi ini, perkembangannya banyak diterapkan oleh para pelaku usaha baik skala kecil, menengah bahkan perusahaan besar sekalipun. Konsinyasi merupakan penyerahan fisik barang-barang oleh pemilik kepada pihak lain, yang bertindak sebagai agen penjual dan biasanya dibuatkan persetujuan mengenai hak yuridis atas barang-barang yang dijual oleh pihak penjual. ${ }^{5}$ Penjualan konsinyasi disebut juga dengan penjualan titipan, pihak yang menyerahkan barang disebut pengamanat atau consignor (konsinyor), sedangkan pihak yang menerima barang tersebut disebut komisioner atau consignee (konsinyi). ${ }^{6}$ Konsinyasi merupakan penyerahan fisik barang-barang oleh pemilik kepada pihak lain, yang bertindak sebagai agen penjual dan biasanya dibuatkan persetujuan mengenai hak yuridis atas barang-barang yang dijual oleh pihak penjual. ${ }^{7}$ Penjualan konsinyasi disebut juga dengan penjualan titipan, pihak yang menyerahkan barang disebut pengamanat atau consignor (konsinyor), sedangkan pihak yang menerima barang tersebut disebut komisioner atau consignee (konsinyi). ${ }^{8}$

Pasal 1701 KUHPerdata yang berbunyi "penitipan barang dengan sukarela hanya dapat dilakukan antara orang-orang yang cakap untuk mengadakan perjanjian. Akan tetapi jika orang yang cakap untuk mengadakan perjanjian menerima titipan barang dan seseorang yang tidak cakap untuk itu, maka ia harus memenuhi semua kewajiban seorang penerima titip murni" ${ }^{9}$

${ }^{4}$ Salim HS, H. Abdullah, dan Wiwiek Wahyuningsih, 2007, Perancangan Kontrak dan Memorandum Of Understanding, PT. Sinar Grafika, Jakarta, hlm. 8.

${ }^{5}$ Aliminsyah dan Padji, op.cit, hlm. 77.

${ }^{6}$ Niken Dian Pratiwi, 4 Juni 2013, Evaluasi Penerapan Sistem Akuntansi, PT Gramedia Asri Media, Surakarta, Fakultas Ekonomi Universitas Sebelas Maret, h.17.

${ }^{7}$ Aliminsyah dan Padji, op.cit, hlm. 77.

8 Niken Dian Pratiwi, 4 Juni 2013, Evaluasi Penerapan Sistem Akuntansi, PT Gramedia Asri Media, Surakarta, Fakultas Ekonomi Universitas Sebeleas Maret,h.27.

${ }^{9}$ Kitab Undang-Undang Hukum Perdata 
PT. Down To Earth merupakan perusahaan Penanaman Modal Asing yang bergerak di bidang perdagangan besar yang menerapkan sistem konsinyasi sehingga dapat menjalankan bisnisnya untuk menekan kerugian akibat dari daya beli konsumen yang tidak menentu. Sistem konsinyasi dilaksanakan berdasarkan prinsip kepercayaan oleh pihak konsinyor dan melalui perjanjian konsinyasi antara pihak konsinyor dan pihak konsinyi berupa perjanjian baku yang dibuat oleh pihak PT. Down To Earth. Di dalam perjanjian bedasarkan asas kebebasan berkontrak, semestinya kedua belah pihak harus secara bersama-sama dalam membuat perjanjian. Namun di dalam standard contract atau perjanjian baku hal tersebut tidak terjadi. Sehingga yang ada adalah kreditur menyodorkan bentuk perjanjian yang berwujud blanko atau formulir dengan klausul-klausul yang sudah ada, kecuali mengenai harga, jenis barang, jumlah serta macamnya saja yang belum terisi. ${ }^{10}$

Sistem konsinyasi dalam praktek tidak jarang terjadi adanya suatu permasalahan yang diakibatkan karena seiring berjalannya pelaksanaan perjanjian kerjasama konsinyasi ada suatu keadaan atau situasi yang diluar dugaan para pihak dalam perjanjian seperti kasus tidak tertibnya konsinyor dalam pengadaan barang yang terjadi di PT. Down To Earth. Perusahaan PT. Down To Earth memiliki 6 outlet yang berada di daerah Seminyak, Sanur, dan Ubud. Pihak konsinyor terkadang mengirim stok baru dan menitipkan barang melalui outlet lalu dikirim ke gudang PT. Down To Earth melalui sopir. Apabila dilihat berdasarkan Perjanjian Konsinyasi PT. Down To Earth pada Pasal 4 menyatakan bahwa "Invoice harus ditandatangani oleh kedua belah pihak pada saat diterima" kedua pihak yang dimaksud adalah pihak konsinyor dan staff gudang karena yang berhak untuk menerima stok masuk adalah pihak gudang bukan pihak outlet. Namun kenyataannya pihak konsinyor mengirim barang seringkali tidak membawa bukti pengiriman atau invoice tetapi bukti pengiriman tersebut dikirim melalui email dan tidak di tandatangani oleh kedua belah pihak. Pelaksanaan administrasi di PT. Down To Earth tidak bisa 'berjalan dengan baik apabila bukti pengiriman tidak ada tanda tangan oleh pihak pengirim barang. Selain kasus dalam administrasi kasus yang sering terjadi

\footnotetext{
${ }^{10}$ Sri Gambir Melati Hatta, op.cit, h. 144.
} 
adalah kehilangan barang. Pada awalnya pihak konsinyor telah setuju dengan perjanjian konsinyasi saat mulai bekerjasama namun setelah berjalannya waktu, banyak yang bertentangan terhadap Pasal 14 Perjanjian Konsinyasi PT. Down To Earth. Pada Pasal 14 Perjanjian Konsinyasi PT. Down To Earth menyatakan bahwa "Consignor menyetujui untuk mengganti barang yang kadaluarsa atau rusak dari produksi tanpa ada biaya tambahan. Dan setiap barang yang hilang di toko akan ditanggung oleh penjual dan pihak konsinyasi 50\%-50\%".

Jadi yang dimaksud adalah apabila salah satu pihak merasa dirugikan maka dapat memilih sanksi yang akan dikenakan terhadap pihak lawannya yang melakukan wanprestasi, yaitu memaksa pihak yang wanprestasi untuk tetap memenuhi perjanjian yang dimaksud atau menuntut pembatalan perjanjian disertai dengan penggantian biaya, kerugian dan bunga. Mengacu pada pengaturan perjanjian konsinyasi dengan memperhatikan pada akibat dari perjanjian yang memberatkan salah satu pihak yaitu konsinyi, penulis merasa terjadi kesenjangan antara das sollen dan das sein dalam pelaksanaan perjanjian konsinyasi di PT. Down To Earth.

Sehingga perlu ditelaah lebih dalam terkait dengan tanggung jawab pihak konsinyor yang melakukan wanprestasi dalam perjanjian konsinyasi pada PT. Down To Earth dan penyelesaian sengketa terkait dengan wanprestasi perjanjian konsinyasi pada PT. Down To Earth

Metode penelitian yang digunakan dalam penelitian ini adalah yuridis empiris. Jenis data yang digunakan yaitu data primer dan data sekunder. Metode pengambilan sampel yang digunakan adalah wawancara dengan informan dari PT. Down To Earth dan pihak responden dari pihak konsinyor yang melakukan wanprestasi.

\section{HASIL PENELITIAN DAN PEMBAHASAN}

A.Tanggung Jawab Pihak Konsinyor yang Melakukan Wanprestasi dalam Perjanjian Konsinyasi pada PT. Down To Earth

Kontrak kerjasama penjualan penitipan atau pola konsinyasi merupakan perjanjian dimana salah satu pihak berperan sebagai pemilik barang atau konsinyor dan pihak yang 
mengusahakan penjualan barang atau konsinyi. Perusahaan yang menerapkan sistem konsinyasi di Kabupaten Badung salah satunya yaitu PT. Down To Earth, Seminyak. Agar bisa bekerjasama konsinyasi dengan PT. Down To Earth, pihak konsinyor atau pemilik barang yang akan mentitipkan barangnya harus memenuhi syarat serta ketentuan yang ditetapkan oleh PT. Down To Earth yaitu berupa mengisi blanko perjanjian konsinyasi sebelum kegiatan konsinyasi dilaksanakan. Perjanjian kerjasama konsinyasi yang dibuat oleh PT. Down To Earth dengan berlandaskan asas kebebasan berkontrak, dimana undang-undang memberikan kebebasan kepada siapa saja yang akan membuat perjanjian, asal tidak bertentangan dengan undang-undang, kesusilaan dan ketertiban umum

Pasal 1320 KUHPerdata yang mengatur syarat sahnya suatu perjanjian yaitu :

1. Sepakat mereka yang mengikat dirinya

2. Cakap untuk membuat suatu perjanjian

3. Mengenai suatu hal tertentu

4. Suatu sebab yang halal

Dua syarat yang pertama yaitu sepakat mereka yang mengikat dirinya dan cakap untuk membuat suatu perjanjian merupakan syarat subyektif mengenai orang orang atau subyek yang mengadakan perjanjian. Sedangkan dua syarat yang terakhir yaitu mengenai suatu hal tertentu dan suatu sebab yang halal merupakan syarat obyektif mengenai perjanjiannya sendiri oleh obyek dari perbuatan hukum yang dilakukan itu. Mengacu pada Pasal 1320 KUHPerdata apabila dikaitkan dengan perjanjian konsinyasi yang ada pada di PT. Down To Earth, yang dimaksud dengan syarat subyektif yaitu kecakapan dan kesepakatan yang tertuang dalam perjanjian antara PT. Down To Earth dengan pihak konsinyor apabila tidak terpenuhi maka perjanjian konsinyasi dapat dibatalkan oleh para pihak dan syarat obyektif yaitu barang yang dititipkan di PT. Down To Earth dan isi perjanjian tidak melanggar peraturan perundang-undangan, jika hal ini tidak dapat terpenuhi maka perjanjian konsinyasi dinyatakan batal demi hukum. 
Kasus wanprestasi yang terjadi di PT. Down To Earth yaitu pengiriman barang, penerimaan nota dan kehilangan barang. Perusahaan PT. Down To Earth memiliki 6 outlet yang berada di daerah Seminyak, Sanur dan Ubud selain itu memiliki Gudang pusat barang di daerah Canggu. Kasus wanprestasi dalam pengiriman barang yaitu pihak konsinyor seringkali mengirim barang melalui outlet dan diterima oleh staff outlet lalu dikirim ke gudang PT. Down To Earth melalui sopir. Seharusnya barang yang dikirim harus melalui gudang dan barang akan diserahkan ke masing-masing outlet, pihak konsinyor tidak berhak mengirim barang melalui outlet karena staff outlet hanya berhak menerima barang dari gudang Canggu. ${ }^{11}$

Kasus wanprestasi selanjutnya yaitu penerimaan nota. Konsinyor sering mengirim nota melalui e-mail kepada staff kantor dan tidak ada tandatangan oleh kedua belah pihak. Seharusnya pada saat konsinyor melakukan pengiriman barang juga harus menyertakan nota dan ditandatangi oleh pihak pengirim yaitu konsinyor dan pihak penerima yaitu pihak gudang. Pelaksanaan administrasi di PT. Down To Earth tidak bisa berjalan dengan baik apabila bukti pengiriman tidak ada tanda tangan oleh pihak pengirim barang. Ada beberapa kendala yang menyebabkan pihak konsinyor mengirim barang langsung ke outlet yaitu pertama karena barang yang dikirim merupakan makanan yang jangka kadaluarsanya pendek hanya 2-3 hari dan yang kedua yaitu pihak konsinyor malas untuk mengirim barang ke Gudang Canggu dikarenakan perusahaan konsinyor jauh dari Gudang sehingga pihak konsinyor mencari alternatif dengan mengirim ke outlet terdekat disebabkan bahwa pihak konsinyor merupakan kerabat owner. ${ }^{12}$ Kedua kasus wanprestasi diatas dapat mengakibatkan kehilangan barang yang terjadi di PT. Down To Earth. Pada awalnya pihak konsinyor telah menyetujui dengan perjanjian konsinyasi saat mulai bekerjasama namun setelah berjalannya waktu, banyak yang bertentangan

${ }^{11}$ Hasil wawancara dengan Ibu Yulia Ambarani selaku pihak Informan di PT. Down To Earth, tanggal 8 Februari 2018

${ }^{12}$ Hasil wawancara dengan Ibu Mirah selaku pihak responden konsinyor di PT. Down To Earth, tanggal 24 Mei 2018 
terhadap Pasal 14 Perjanjian Konsinyasi PT. Down To Earth menyatakan bahwa "Konsinyor menyetujui untuk mengganti barang yang kadaluarsa atau rusak dari produksi tanpa ada biaya tambahan. Dan setiap barang yang hilang di toko akan ditanggung oleh penjual dan pihak konsinyasi 50\%-50\%" pada kenyataannya pihak konsinyor ingin barang yang hilang harus dibayarkan sepenuhnya tidak dengan membayar hanya $50 \%$ dari harga pokok barang tersebut.

Secara yuridis dalam ketentuan Pasal 1697 KUHPerdata menyatakan bahwa "Perjanjian penitipan belum terlaksana sebelum barang yang bersangkutan diserahkan betul-betul atau dianggap sudah diserahkan". Jika dikaitkan dengan kasus penerimaan barang dengan nota tanpa tandatangan oleh kedua belah pihak, perjanjian penitipan dianggap belum diserahkan dikarenakan syarat dan ketentuan yang ada pada perjanjian konsinyasi harus ditandatangani oleh kedua belah pihak sedangkan penyerahan nota terkadang tanpa tandatangan oleh kedua belah pihak.

Kasus wanprestasi pengiriman barang dan penerimaan nota apabila dilihat pada Pasal 4 Perjanjian Konsinyasi PT. Down To Earth "Dalam proses pengiriman produk, konsinyor harus menyertakan invoice lengkap barang yang akan dikonsinyasikan kepada penjual. Didukung dengan bukti pengiriman dan invoice harus ditandatangani oleh kedua belah pihak pada saat diterima" jadi yang dimaksud adalah ketika pihak konsinyor mengirim barang harus menyertakan nota ketika barang tersebut dikirim dan tidak melalui e-mail.

Kegiatan konsinyasi ini memungkinkan terjadinya keadaan dimana pihak konsinyi (PT. Down To Earth) tidak bertanggung jawab atas kerusakan dan atau kehilangan barang milik konsinyor sebagai akibat tidak tercantumnya klausul mengenai tanggung jawab atas barang tersebut. Hal tersebut sesuai dengan pendapat dari Munir Fuady mengenai karakteristik konsinyasi yang pertama yaitu karena hak milik atas barang masih berada pada konsinyor dan yang ketiga yaitu pihak konsinyor sebagai pemilik tetap bertanggung jawab sepenuhnya terhadap semua biaya yang 
berhubungan dengan barang-barang konsinyasi sejak saat pengiriman sampai saat konsinyi berhasil menjualnya pada pihak ketiga kecuali ditentukan lain dalam perjanjian diantara kedua belah pihak, maka barang konsinyasi harus dilaporkan sebagai persediaan oleh konsinyor. ${ }^{13}$ Yang dimaksud adalah apabila terjadi suatu hal terhadap barang yang dititipkan diluar kehendak pihak konsinyi atau PT. Down To Earth seperti kehilangan barang sebelum barang tersebut sampai ke pihak ketiga yaitu pembeli, hak milik tetap masih berada pada konsinyor. Jika dikaitkan dengan asas itikad baik yang tercantum pada Pasal 1338 KUHPerdata yang menjelaskan bahwa "Perjanjian harus dilaksanakan dengan itikad baik". Dalam hal ini pihak PT. Down To Earth memiliki itikad baik dengan mengganti setengah harga dari harga pokok sesuai Pasal 14 perjanjian konsinyasi PT. Down To Earth, sehingga pihak PT. Down To Earth tetap bertanggung jawab atas kejadian kehilangan barang.

Wanprestasi atau ingkar janji adalah tidak terpenuhinya kewajiban (prestasi) sebagaimana yang ditentukan dalam perjanjian yang dibuat antara kreditur dan debitur. ${ }^{14}$ Akibat yang timbul oleh debitur (pihak konsinyor) yang melakukan wanprestasi dalam suatu perjanjian konsinyasi atau titip jual dimana debitur tidak memenuhi kewajibannya atau melakukan hal-hal diluar haknya sebagai konsinyor adalah tidak dapat terpenuhinya isi dari perjanjian atau tidak terlaksananya isi dari perjanjian sebagaimana mestinya yang menyebabkan kreditur (pihak PT. Down To Earth) tidak mendapatkan pemenuhan hak-haknya yang semestinya didapatkan sesuai dengan perjanjian konsinyasi yang telah dibuat. Kreditur yang tidak mendapatkan pemenuhan atas hak-haknya, mengakibatkan kreditur mengalami kerugian. Oleh karena itu debitur yang tidak melaksanakan kewajibannya harus bertanggung jawab atas kerugian tersebut. Kerugian yang diderita oleh pihak PT. Down To Earth tersebut disebabkan akibat adanya wanprestasi dari

${ }^{13}$ Munir Fuady, 2001, Hukum Kontrak dari Sudut Pandang Hukum Bisnis, PT. Citra Aditya Bakti, Bandung, h. 42.

${ }^{14}$ Rocky Marbun, 2011, Kasus Hukum, Visimedia, Jakarta, h. 201. 
pihak konsinyor.

R. Subekti mengemukakan bahwa wanprestasi itu adalah kelalaian atau kealpaan yang dapat berupa 4 macam yaitu :

1. Tidak melakukan apa yang telah disanggupi akan dilakukannya

2. Melaksanakan apa yang telah diperjanjikannya, tetapi tidak sebagaimana yang diperjanjikan

3. Melakukan apa yang diperjanjikan tetapi terlambat

4. Melakukan suatu perbuatan yang menurut perjanjian tidak dapat dilakukan ${ }^{15}$

Sesuai pendapat Subekti mengenai Wanprestasi apabila dikaitkan dengan kasus yang terjadi di PT. Down To Earth, konsinyor melaksanakan apa yang telah diperjanjikannya, tetapi tidak sebagaimana yang diperjanjikan. Hal ini sangat jelas dimana pihak konsinyor melakukan wanprestasi karena tidak mengikuti dan mentaati peraturan yang berlaku di PT. Down To Earth sehingga menyebabkan keadaan diluar dugaan para pihak seperti kehilangan barang.

Menurut Abdulkadir Muhammad teori tanggung jawab dalam perbuatan melanggar hukum (tort liability) dibagi menjadi beberapa teori, yaitu :

1. Tanggung jawab akibat perbuatan melanggar hukum yang dilakukan dengan sengaja (intertional tort liability), tergugat harus sudah melakukan perbuatan sedemikian rupa sehingga merugikan penggugat atau mengetahui bahwa apa yang dilakukan tergugat akan mengakibatkan kerugian.

2. Tanggung jawab akibat perbuatan melanggar hukum yang dilakukan karena kelalaian (negligence tort liability), didasarkan pada konsep kesalahan (concept of fault) yang berkaitan dengan moral dan hukum yang sudah bercampur baur (interminglend).

3. Tanggung jawab mutlak akibat perbuatan melanggar hukum tanpa mempersoalkan kesalahan (strick liability), didasarkan pada perbuatannya baik secara sengaja maupun tidak

15 Ridwan Khairandy, 2014, Hukum Kontrak Indonesia, FH UII Press, Yogyakarta, h. 280. 
sengaja, artinya meskipun bukan kesalahannya tetap bertanggung jawab atas kerugian yang timbul akibat perbuatannya. ${ }^{16}$

Perbuatan melanggar hukum (tort liability) pada teori tanggung jawab hukum menurut Abdulkadir Muhammad jika dikaitkan dengan kasus yang ada yaitu pihak konsinyor tidak tertib dengan peraturan perjanjian konsinyasi sehingga sangat menghambat sistem administrasi dan terjadinya kehilangan barang akibat pihak konsinyor tidak mentaati peraturan yang berlaku. Pada prinsipnya tanggung jawab konsinyor sebagai penyalur barang yang akan dijual di PT. Down To Earth harus mengikuti SOP (Standar Operasional Perusahaan) yang berlaku. Tanggung jawab yang dimaksud ialah tanggung jawab mentaati peraturan yang ada agar membantu memperlancar sistem kegiatan konsinyasi yang dilaksanakan di PT. Down To Earth seperti mengirim barang ke tempat yang telah ditentukan yaitu gudang Canggu karena apabila pengiriman barang oleh pihak konsinyor langsung ke outlet tidak melalui gudang menyebabkan kekacauan dalam sistem administrasi dan sangat besar kemungkinan akan terjadi kehilangan barang. Apabila kita berbicara mengenai pertanggung -jawaban hukum, maka kita juga harus berbicara tentang ada tidaknya suatu kerugian yang telah diderita oleh suatu pihak sebagai akibat tidak tertibnya peraturan yang sudah disepakati sebelumnya. Kerugiannya yang diderita oleh pihak PT. Down To Earth berupa membayar kehilangan barang yang diambil oleh pihak yang tidak bertanggung jawab, sehingga pihak PT. Down To Earth membayar $50 \%$ dari harga pokok tersebut dimana seharusnya PT. Down To Earth mendapatkan keuntungan dari penjualan namun dalam hal ini PT. Down To Earth mengalami kerugian.

Maka mengacu kepada ketentuan Pasal 1365 KUHPerdata maka sudah seharusnya para konsinyor juga turut memberikan ganti kerugian terhadap perusahaan, baik ganti kerugian materiil yang berupa uang atau barang baru maupun ganti kerugian

16 Abdulkadir Muhammad, 2010, Hukum Perusahaan Indonesia, Citra Aditya Bakti, Bandung, h. 503 
inmateriil berupa permohonan maaf dan akan mengikuti sistem konsinyasi sesuai dengan peraturan peraturan yang berlaku.

\section{B. Penyelesaian Sengketa Wanprestasi Perjanjian Konsinyasi pada PT. Down To Earth}

Konflik umumnya berawal dari perbedaan pandangan atau kepentingan yang terjadi antara para pihak, yang kemudian dipertajam sehingga memunculkan konflik yang sebenarnya. Di dalam dunia bisnis, konflik berawal dari adanya pertentangan kepentingan antara para pelaku bisnis. Konflik dalam dunia bisnis selalu tidak menguntungkan antara kontra dan produktif dengan tujuan bisnis. Oleh karena itu konflik atau sengketa yang terjadi harus cepat diselesaikan oleh para pihak dengan menggunakan lembaga atau pranata yang tersedia. Pada umumnya penyelesaian sengketa dapat diselesaikan melalui 2 jalur yaitu melalui jalur litigasi (penyelesaian sengketa melalui jalur pengadilan) dan jalur non litigasi (penyelesaian sengketa yang dilakukan diluar pengadilan). Dalam kaitannya Alternatif Penyelesaian Sengketa atau Arbitrase sebagai pilihan untuk menyelesaikan sengketa yang biasa digunakan oleh pelaku bisnis guna mencapai jalan keluar yang winwin solution. Melalui proses diluar pengadilan yang menghasilkan kesepakatan win-win solution dijamin kerahasiaan sengketa para pihak dan tetap menjaga hubungan baik para pelaku bisnis. Satusatunya kelebihan proses diluar pengadilan ini sifat kerahasiaannya karena proses persidangan dan bahkan hasil keputusannya pun tidak dipublikasikan. Dengan demikian penyelesaian sengketa akan berjalan dengan efektif dan efisien serta tidak perlu melibatkan Pengadilan Negeri untuk melakukan eksekusi.

Undang-Undang yang mengatur tentang Arbitrase dan Alternatif Penyelesaian Sengketa yaitu Undang-Undang No. 30 Tahun 1999 yang digunakan menetukan kesepakatan penyelesaian sengketa atau beda pendapat secara tertulis adalah final dan mengikat bagi para pihak untuk dilaksanakan dengan itikad baik. Menurut Pasal 1 ayat 10 Undang-Undang No 30 Tahun 1999 yang mengatur tentang Arbitrase dan Alternatif Penyelesaian Sengketa 
menyatakan bahwa "Alternatif Penyelesaian Sengketa adalah lembaga penyelesaian sengketa atau beda pendapat melalui prosedur yang disepakati para pihak, yakni penyelesaian di luar pengadilan dengan cara konsultasi, negosiasi, mediasi, konsiliasi atau penilaian ahli"17

Upaya penyelesaian sengketa wanprestasi yang terjadi dengan konsinyor di PT. Down To Earth jika dilihat berdasarkan Perjanjian Konsinyasi apabila terjadinya sengketa akan menempuh jalur litigasi, namun para pihak bebas untuk memilih jalur litigasi maupun non litigasi berdasarkan asas kebebasan berkontrak. ${ }^{18}$ Penyelesaian sengketa di PT. Down To Earth bersama pihak konsinyor pada awalnya melakukan negosiasi bertujuan untuk mencapai suatu kesepakatan dalam berbisnis. Dengan melakukan upaya negosiasi para pihak berharap menemukan jalan keluar dari masalah yang dihadapi bersama. Pada saat negosiasi pihak PT. Down To Earth bersama pihak konsinyor melaksanakan perundingan menyelesaikan masalah yang terjadi. Ketika perundingan berlangsung pihak PT. Down To Earth menghadapi kesulitan mendapatkan data nota pengiriman dari pihak konsinyor, PT. Down To Earth berharap akan mencocokkan data dengan pihak konsinyor. Sehingga pihak konsinyor dan pihak PT. Down To Earth berupaya melibatkan pihak ketiga yang netral dengan memilih jalur mediasi yang dibantu oleh mediator dari salah satu pihak Lembaga Hukum yang ada di Denpasar. Adapun tahapan proses mediasi yang dilakukan yaitu :

1. Pihak PT. Down To Earth tetap membayar kehilangan barang $50 \%$ dari total harga barang yang hilang di PT. Down To Earth karena sesuai perjanjian konsinyasi yang sudah dijanjikan sebelumnya tidak bisa diubah, karena para pihak sudah menyetujui pada awal perjanjian.

2. Pihak konsinyor akan mengikuti sistem konsinyasi sesuai perjanjian agar tidak terjadi kehilangan barang dikemudian hari

17 Undang-Undang No. 30 Tahun 1999 Tentang Arbitrase dan Alternatif Penyelesaian Sengketa.

${ }^{18}$ Hasil wawancara dengan ibu Ayu selaku pihak responden mediator di PT. Down To Earth, tanggal 5 Juli 2018 


\section{KESIMPULAN}

Berdasarkan pembahasan pada bab di atas maka dapat ditarik kesimpulan sebagai berikut :

1. Tanggung jawab konsinyor yang melakukan wanprestasi yakni memberikan ganti kerugian terhadap perusahaan, baik ganti kerugian materiil yang berupa uang atau barang baru maupun ganti kerugian inmateriil berupa permohonan maaf dan akan mengikuti sistem konsinyasi sesuai dengan peraturan peraturan yang berlaku.

2. Upaya penyelesaian sengketa yang digunakan oleh PT. Down To Earth dalam menyelesaikan kasus wanprestasi yang dilakukan oleh pihak konsinyor adalah penyelesaian sengketa melalui jalur non litigasi yaitu pada awal terjadinya sengketa para pihak melalui negosiasi namun dalam proses penyelesaian negosiasi tidak tercapai kemudian para pihak berupaya menyelesaikan sengketa melalui jalur mediasi.

\section{DAFTAR PUSTAKA}

\section{Buku:}

Aliminsyah, Padji, 2003, Kamus Istilah Keuangan dan Perbankan, Yrama Widya, Bandung

Fuady, Munir, 2001, Hukum Kontrak dari Sudut Pandang Hukum Bisnis, PT. Citra Aditya Bakti, Bandung

Hatta,Sri Gambir Melati, 2000, Beli Sewa Sebagai Perjanjian Tak Bernama:

Pandangan Masyarakat dan Sikap Mahkamah Agung Indonesia, Alumni, Bandung

Khairandy, Ridwan, 2014, Hukum Kontrak Indonesia, FH UII Press, Yogyakarta

Marbun, Rocky, 2011, Kasus Hukum, Visimedia, Jakarta.

Muhammad, Abdulkadir, 2010, Hukum Perusahaan Indonesia, PT. Citra Aditya Bakti, Bandung

Pratiwi, Niken Dian, 4 Juni 2013, Evaluasi Penerapan Sistem Akuntansi, PT Gramedia Asri Media, Surakarta, Fakultas Ekonomi Universitas Sebeleas Maret

Royan, Frans, M., 2004, Creating Effective Sales Force, Ed.2, CV. Andi Offset, Jakarta 
Salim HS, H. Abdullah, dan Wiwiek Wahyuningsih, 2007, Perancangan Kontrak dan Memorandum Of Understanding, PT. Sinar Grafika, Jakarta

\section{Peraturan Perundang-Undangan:}

Kitab Undang-Undang Hukum Perdata

Undang-Undang No. 30 Tahun 1999 Tentang Arbitrase dan Alternatif Penyelesaian Sengketa 